\title{
The Effect of Principal Leadership and Classroom Management on Teacher Performance in SD Negeri Sungai Menang District
}

\author{
Gunawan Eka Susila ${ }^{1 *}$, Bukman Lian ${ }^{1}$, Mulyadi $^{1}$ \\ ${ }^{1}$ Universitas PGRI Palembang \\ *Corresponding author. E-mail: gunawanekasusila@gmail.com
}

\begin{abstract}
The purpose of this study was to provide answers to assumptions about the influence of principal leadership and classroom management on teacher performance. For this reason, researchers use quantitative descriptive research methods so that the information obtained can be tested through the formulated hypothesis. The results of the research conducted state that it is true that the principal's leadership is able to have a positive and significant effect on teacher performance; Likewise, classroom management provides a positive and significant contribution to teacher performance if a partial test is carried out. For simultaneous testing, the two variables simultaneously (principal leadership and classroom management) have a positive and significant effect on teacher performance in public elementary schools in Sungai Menang District.
\end{abstract}

Keywords: principal leadership, classroom management, teacher performance.

\section{INTRODUCTION}

The quality of education in Indonesia nationally will be greatly influenced by the quality of learning held in schools. The implementation of learning in schools is carried out professionally by the teacher, as the spearhead in educating, guiding, directing and transforming knowledge to students. Therefore, it is very important to understand and optimize the performance of a teacher in the learning process.

Many things can have an influence on the performance of a teacher, both from the internal side of the teacher and from the external side of the teacher. There are many factors when viewed from the external aspect of the teacher, including because of colleagues or colleagues, school management, leadership who has authority in schools and class management within the scope of the school [1].

Apart from these factors, teachers as professionals must have good performance. Especially regarding their professional duties as stated in the Regulation of the Minister of Education and Culture Number 23 of 2017, article 1 paragraph (3) states that teachers are professional educators with the main task of educating, teaching, guiding, directing, training, assessing, and evaluating students in education. Early childhood formal education, basic education, and secondary education [2].

The obligation of a teacher is to educate the nation's generation to lead a future Indonesia. The delegation of tasks is also regulated in Law Number 14 of 2005 concerning Teachers and Lecturers, article 1 paragraph (1) emphasizes that teachers are professional educators with the main task of educating, teaching, guiding, directing, training, assessing, and evaluating students at Early childhood education through formal education, basic education, and secondary education [3]

The teacher as an educator, who is at the forefront of transforming values and knowledge to students in the school environment must declare that learning carried out in class is able to achieve national educational goals. It is clearly stated in Law Number 20 of 2003 concerning the National Education System in article 3 that the goal of national education is to develop the potential of students to become human beings who believe and fear God Almighty, have noble character, are healthy, knowledgeable, capable, creative, 
independent, and become citizens who are democratic and responsible [4].

Various regulations regarding the responsibilities of a teacher, especially in order to achieve the goals of national education have been described. This is important to understand as the basis that teachers have the authority as well as the obligation to achieve this through optimal performance in the implementation of learning. As previously described, the principal's leadership is one of the things that is believed to have an impact on the performance of a teacher who is carrying out his duties at school.

The leadership role of the principal in the delivery of education in schools includes the process of moving, influencing, motivating and directing people in the organization or educational institution, especially to achieve the goals that have been formulated. Therefore, principals are required to have the ability to guide, mobilize and encourage and direct people in educational institutions, namely achieving educational goals that have been formulated previously [5].

The principal is the highest official in the school institution. Therefore, a school principal is the main structural and administrative person in charge of the school. As the principal of the school, he also functions as a leader who carries out his leadership in the school. Teachers and school employees are their subordinates who are under the authority of the school principal in carrying out their duties [6].

The leadership of the principal as an education administrator has responsibility for the smooth implementation of education and teaching in his school. The principal must be able to face various problems at school, think analytically and conceptually and must always try to become an intermediate teacher in solving various problems faced by the education staff who are under him, and try to make decisions that are satisfactory for all [7].

So, a principal must really understand his obligations and authorities so that he can continue to lead the school to achieve educational goals. Another form of authority is class management. In principle, the class is managed by the teacher who organizes the learning, but class management can also be controlled by the principal as part of his authority to oversee the learning process. The definition of classroom management refers to the opinion [8] that classroom management means classroom management activities for teaching purposes. Classroom management is a teacher's skill to create a conducive learning climate and control it if there is a disruption in learning.

Likewise with the leadership carried out by the principal, everyone has the right to give their perceptions from a perspective that is understood subjectively. Researchers found a phenomenon that the teacher's dislike of the leader will also cause dislike for the principal of the teacher concerned. So that the guiding and directing functions that should be owned by the principal is not yet obvious [23]; [24].

The phenomena that occur in the research location indicate that the perceptions of each teacher of the leadership carried out by the principal will have an impact on the teacher's performance. This can also be seen from the collection of learning equipment on time, as an indication that the teacher's performance at the school is not yet optimal.

\section{METHODS}

The research was conducted at SD Negeri Sungai Menang District, Ogan Komering Ilir Regency. Starting from July to October 2020. This research uses a quantitative descriptive method. [9] said that the quantitative approach is the approach used by researchers in research by measuring variable indicators so that an overview and conclusions of the research problem can be obtained. The quantitative approach is a method of problem solving that is planned and careful, with a tightly structured design, systematically controlled data collection and is aimed at developing theories that are concluded inductively within the framework of empirically proving hypotheses [10]

This type of descriptive research with a quantitative approach is the type used in this research. [11] argues that the quantitative research method is a research method based on the philosophy of positivism, used to research on certain populations or samples, data collection using research instruments, quantitative data analysis, with the aim of testing predetermined hypotheses. Quantitative methods are used in this study because the information or data obtained is in the form of numbers, then processed based on numbers so that the results are in the form of numbers as proof of the hypothesis and answer the formulation of the research problem.

A total of 69 people were sampled from a total population of 243 people. To obtain data from the research sample, a questionnaire was used as well as observations and documentation. Then the data is analyzed through parametric statistics.

\section{RESULTS AND DISCUSSION}

Before testing the hypothesis, the prerequisite data has been tested which states that the data is normally distributed and there are no symptoms of heteroscedasticity.

Testing the first hypothesis obtained the results of tcount of 2.815> t table, namely 1.996, which means that the leadership of the principal has a positive and significant effect on the performance of teachers in SD Negeri in Sungai Menang District, Ogan Komering Ilir Regency. 
The correlation coefficient or the magnitude of the relationship between principal leadership and teacher performance is $32.5 \%$, and is included in the weak relationship category. The determinant coefficient or the magnitude of the influence of the principal's leadership variable on teacher performance is $10.6 \%$, which means it has a very low influence.

Testing on the second hypothesis, it is stated that the value of $t>t$ table; 3,066>1,996. Based on this, it is stated that classroom management has a positive and significant effect on the performance of teachers in SD Negeri in Sungai Menang District, Ogan Komering Ilir Regency.

The correlation coefficient or the magnitude of the relationship between classroom management and teacher performance is $35.1 \%$. The magnitude of the relationship is in the weak category. The determinant coefficient or the magnitude of the influence of the classroom management variable on the performance of teachers in SD Negeri in Sungai Menang District, Ogan Komering Ilir Regency is $12.3 \%$ and is included in the very low influence category.

For simultaneous testing, it was obtained that the Fcount value was 5.367> FTabel of 3.136, which means that there was a positive and significant influence on the principal's leadership and classroom management on the performance of teachers in SD Negeri in Sungai Menang District, Ogan Komering Ilir Regency.

As much as $37.4 \%$ collectively, the principal's leadership and classroom management have a relationship with the performance of teachers in SD Negeri in Sungai Menang District, Ogan Komering Ilir Regency, thus it is included in the weak relationship category. The leadership of the principal and class management jointly affect the performance of teachers in SD Negeri in Sungai Menang District, Ogan Komering Ilir Regency by $14.0 \%$ and is included in the very low influence category.

\subsection{The influence of principal leadership on teacher} performance

The results obtained through this study also confirm previous research conducted by [12] which states that principal leadership is able to have a positive impact on the performance of teachers who teach. That is why this research is also one of the relevant studies. Another study was also conducted by [13] that principal leadership has a positive impact on teacher performance. That way the results obtained from the research conducted also confirm this research.

The same is the case with research conducted by [14]; [15]; and [16]. These studies have been confirmed from the results achieved from this study. Likewise with several previous studies as reviewed by [17]; [18] who have the conclusion that it is important for a school principal to implement leadership that is acceptable to all elements of the school community. Because then it can participate in optimizing teacher performance [21].

\subsection{Effect of classroom management on teacher} performance

The results of this study support the research conducted by [19] that correct classroom management can have a positive impact on the implementation of learning in the classroom. Therefore, it is normal for classroom management to participate in influencing teacher performance even though the influence is not so big.

3.3. The influence of principal leadership and classroom management on teacher performance

The effect that is evidenced by the two independent variables on the dependent variable, also supports the study [20]; [21]; [22]; [23] which states that teacher performance can be influenced by good principal leadership, if this happens then not only the teacher's performance will be better but will also increase the potential for career development of the teacher [24]; [25].

\section{CONCLUSION}

From the results of data analysis and processing and discussion of the findings of this study, it is stated that: 1) Principal leadership has a positive and significant effect on teacher performance; 2) Classroom management has a positive and significant effect on teacher performance; 3) The leadership of the principal and class management together have a positive and significant effect on the performance of SD Negeri teachers in Sungai Menang District, Ogan Komering Ilir Regency. The magnitude of influence simultaneously is fourteen percent and is included in the very low influence category.

\section{ACKNOWLEDGMENT}

Researchers would like to thank all parties who participated in the implementation of this research, especially the PGRI Palembang University and the Ogan Komering Ilir District Education Office.

\section{REFERENCES}

[1] Susanto, H. (2012). Faktor-faktor yang mempengaruhi kinerja guru Sekolah Menengah Kejuruan. Jurnal Pendidikan Vokasi, Volume 2 Nomor 2, 197-212.

[2] Kementerian Pendidikan dan Kebudayaan. (2017). Peraturan Menteri Pendidikan dan Kebudayaan Nomor 23 Tahun 2017 tentang Hari Sekolah. Jakarta: Kementerian Pendidikan dan Kebudayaan.

[3] Pemerintah Republik Indonesia. (2005). UndangUndang Nomor 14 Tahun 2005 tentang Guru dan Dosen. Jakarta: Pemerintah Republik Indonesia.

[4] Kementerian Pendidikan Nasional. (2003). 
Undang-undang Nomor 20 Tahun 2003 tentang Sistem Pendidikan Nasional. Jakarta: Kementerian Pendidikan Nasional.

[5] Arifin, Z. (2014). Evaluasi Pembelajaran. Bandung: PT. Remaja Rosdakarya..

[6] Herabudin. (2009). Administrasi dan supervisi pendidikan. Bandung: Pustaka Setia.

[7] Mulyasa. (2013). Menjadi kepala sekolah profesional. Bandung: Remaja Rosdakarya.

[8] Fathurrochman, I., Budiman, D. A., \& Alamsyahril, M. K. Revitalization Management Of Islamic Boarding School Preventing The Radicalism.

[9] Djamarah, S. B., \& Zain, A. (2006). Strategi belajar mengajar. Jakarta: Rineka Cipta.

[10] Arikunto, S. (2013). Prosedur penelitian suatu pendekatan praktik. Jakarta: Rineka Cipta.

[11] Hartono, J. (2011). Metodologi penelitian bisnis. Yogyakarta : BPFE.

[12] Sugiyono. (2017). Metode Penelitian Kualitatif, Kuantitatif dan R\&D. Bandung: Alfabeta

[13] Setiyati, S. (2014). Pengaruh kepemimpinan kepala sekolah, motivasi kerja dan budaya sekolah terhadap kinerja guru. Jurnal Pendidikan Teknologi dan Kejuruan, 200-207.

[14] Djatmiko, E. (2006). Pengaruh kepemimpinan kepala sekolah dan sarana prasarana terhadap kinerja guru SMP Negeri Kota Semarang. Fokus Ekonomi, Volume 1 Nomor 2, 19-30.

[15] Nurdin, F. (2017). Pengaruh kepemimpinan kepala sekolah terhadap kinerja guru honorer di SD Negeri 33/5 Mattoanging Kabupateng Pingkep. Makassar: Universitas Islam Negeri Alauddiin Makassar.

[16] Septiana, R., Ngadiman, \& Ivada, E. (2013). Pengaruh kepemimpinan kepala sekolah dan motivasi kerja terhadap kinerja guru SMP Negeri Wonosari. Jurnal Pendidikan Ekonomi, Volume 2 Nomor 1, 107-118.

[17] Purwoko, S. (2018). Pengaruh kepemimpinan kepala sekolah, komitmen guru, disiplin kerja guru, dan budaya sekolah terhadap kinerja guru SMK. Jurnal Akuntabilitas Manajemen Pendidikan, Volume 6 Nomor 2.
[18] Zamroni, M., Nurkolis, \& Yuliejantiningsih, Y. (2017). Pengaruh gaya kepemimpinan kepala sekolah dan motivasi kerja guru terhadap kinerja guru SMP Se-Kecamatan Kersana Kabupaten Brebes. e-jurnal UPGRIS.

[19] Kusen, R. H., Yanto, M., Fathurrochman, I., \& Suhermanto, H. (2020). Increasing Student Understanding of Islamic Education through the Application of Contextual Learning in the Effort to Proving an Understanding of the Radicalism Dangers in Senior High School. Journal of Talent Development and Excellence, 12(1), 5401-5415.

[20] Zakiyah. (2019). Pengaruh kepemimpinan kepala sekolah, kinerja guru dan media pembelajaran terhadap prestasi peserta didik di SMA Negeri 1 Purworejo. Journal Ar-Rihlah Inovasi Pengembangan Pendidikan Islam, Volume 4 Nomor 1, 144-165.

[21] Nanda, A. (2019). Pengaruh pengelolaan kelas dan kinerja guru terhadap prestasi belajar siswa pada mata pelajaran ekonomi. Aceh: Universitas Malikussaleh

[22] Rukmana, A. (2018). Pengaruh gaya kepemimpinan kepala sekolah dan motivasi kerja guru terhadap kinerja guru. Coopetition, Volumen 9 Nomor 1, 77-93.

[23] Priyono, \& Rahayu, A. (2016). Pengaruh gaya kepemimpinan kepala sekolah, motivasi kerja, dan kedisiplinan terhadap pengembangan karier guru SMK di Kabupaten Boyolali. QUALITY, Volume 4 Nomor 1, 25-44.

[24] I. Fathurrochman, S. Danim, S. A. Ab, and N. Kurniah, "The School Principals" Role in Education Management at the Regional Level: An Analysis of Educational Policy in the Industrial Revolution 4 . 0," no. 532, pp. 237-242, 2021.

[25] Imam Tobroni, S. R., Pelana, R., Sianipar, G., Guefara, R. L., \& Fathurrochman, I. (2020). Covid 19: Political Cooperation and Ritual Modification of Religious Worship Through Large-Scale Social Restrictions. Systematic Reviews in Pharmacy, 11(12), 644-648. 